experts en matière de ressources naturelles et les communautés locales visant à informer les décideurs de la vision du public de ce que sont les forêts de la C.-B. et d'identifier les domaines permettant que soit amélioré l'aménagement à long terme. Les résultats intérimaires retenus sont :

- Si l'aménagement forestier doit être réalisé à partir d'une vision commune de ce que sont les forêts, douze principaux défis devront être relevés par les professionnels et les décideurs en C.-B. selon les commentaires émis par 37 chefs de file du secteur forestier de la province et

- Les communautés sont inquiètes de l'avenir de leurs forêts et veulent être plus impliquées dans les décisions, avoir plus d'informations sur létat de la forêt et requièrent que les décideurs entreprennent des travaux d'aménagement forestier qui contribueront au maintien d'une industrie forestière locale qui soit viable et durable.

Labsence de leadership au sein de l'industrie et du gouvernement en matière d'aménagement forestier en C.-B. limitera les possibilités de contrecarrer lorientation actuelle. Les principales ONGE, même si elles partagent les mêmes inquiétudes sur l'avenir des terres forestières de la C.-B., portent leur attention sur des enjeux planétaires comme les changements climatiques.
Les forestiers professionnels du gouvernement, de l'industrie et du secteur de la consultation sont restreints dans leur plaidoyer public en tant qu'individus et forcés de suivre les pratiques et les politiques actuelles supportées par leurs employeurs ou leurs clients. Qui devrait assumer le leadership sur cette question? Les communautés et les organisations professionnelles ont reçu un mandat de la part du public, si elles décident de l'exercer. À ce jour, l'Association of BC Forest Professional (ABCPF) a réservé ses quelques efforts d'affirmation à des réunions à huis clos avec le gouvernement et a rédigé quelques articles dans les journaux, le plus récent appuyant l'aménagement forestier actuel. En ce qui me concerne, ce genre de mesures cherchant à éviter l'aliénation de l'industrie ou du gouvernement ne rend pas service aux membres ou au public. L'Institut forestier du Canada, au niveau national et à celui de ses sections locales, a posé des gestes concrets pour devenir un partenaire d'avant plan de l'initiative HFHC. Ce positionnement en tant que chef de file a été bien accueilli. Les communautés (autochtones et non autochtones) ont des moyens limités (financement et expertise) mais désirent clairement être impliquées. Cependant, elles veulent être conseillées par des forestiers professionnels.

Lorientation de l'industrie forestière

et du gouvernement, létat des finances, les réductions d'effectifs parmi les forestiers professionnels, les défis identifiés par les chefs de file de la C.-B. en matière d'aménagement forestier et les attentes des communautés requièrent que la profession ainsi que ses membres, mettent en place des mesures sans précédent pour accroître l'importance de l'aménagement forestier aux yeux des décideurs. C'est une opportunité offerte à l'IFC et/ou à l'ABCFP d'assumer un rôle de leadership, avec l'appui du monde universitaire, des communautés et des Premières Nations. Toutefois, cela implique une volonté de s'impliquer de façon marquée par des messages basés sur des faits scientifiques, de la documentation étayée et de la passion. Les forestiers professionnels constituent le seul groupe viable et capable de s'engager à relever cet important enjeu. Est-ce que l'IFC et/ou l'ABCPF iront de l'avant et se joindront aux communautés et au monde universitaire pour assurer que les terres forestières de la C.-B. répondront aux attentes du public à long terme? Je suivrai avec attention les échanges sur ce sujet au cours des prochains mois.

Bill Bourgeois, $\mathrm{Ph} \mathrm{D}, \mathrm{RPF}$

Président, New Direction Resource Management Ltd

PERSPEGTIIE

\title{
The Meaning of Life!!!
}

O

kay. Let's get serious for a minute. If you take the title of this piece as is and you are actually reading this with the thought that I will provide some insight into the topic, then great. At least I got you reading.

So please, keep reading but in all seriousness the meaning of life escapes me and this Perspective will only touch briefly on the subject if at all. I had a really great time this past August as I was with the Newfoundland and Labrador CIF/IFC Section on a summer field tour. Over an evening and the better part of the next working day we had a barbeque with refreshments, a full breakfast, coffee break with muffins and a great field lunch! Wow! We also enjoyed the day touring the North Pond Experimental Field Station-just a great CIF/IFC day.

The North Pond experimental field station is a Canadian Forest Service field experimental site that turned 50 this year and this tour was a both a celebration of all those years of work and a "trip down memory lane" for many of us. For other and younger members it

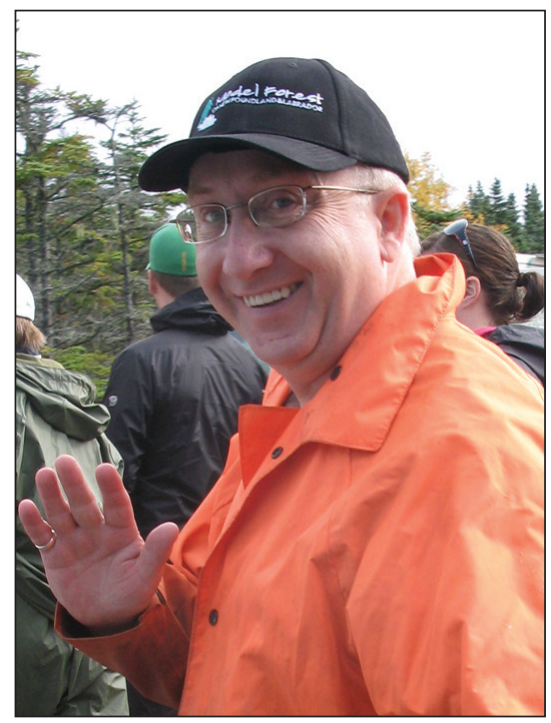

Wayne T. Kelly, R.P.F. CIF/IFC President/président 
was a chance to see the results of some interesting silviculture trials that were conceived, planned and implemented primarily in the mid-1960s and early 1970s. It was also a chance to meet and reconnect with some foresters and researchers from that era. The field tour was well attended, the weather was great (always a bonus here in Newfoundland), the food great and plentiful, and with the Province's newest CL 415 water bomber giving us a few flybys over lunch.

What was also great about the field tour, were two things. The experiments were interesting-many tree species planted, provenances tested, trials replicated. The North Pond site is about six square miles in size, and grew from the ashes of the 1961 forest fires that ravaged the island. The Canadian Forest Service was relatively young in the Province at that time and some early foresters and researchers had connections to the British Isles (Scotland) and British Columbia. Hence some early trials had a somewhat Commonwealth flavor. Species from the Pacific coast, which were common plantings in postwar Britain, were included in the trials (many did not survive the harsh climate). Other more common boreal species were also planted and produced variable results.

As noted above, the field tour was well attended. We had younger foresters on the tour that enjoyed the day but a couple of groups that really seemed to appreciate the outing were guys like me who are nearing retirement and had spent part of our student days measuring (and measuring!) bits and pieces of the trials as well as a very special group of guys who retired some time ago. I will mention names because they are some pretty special people: Ed Blackmore was there and he organized the field tour. Ed is a long-time CIF/IFC member, a Tree of Life award winner and a very active member in his retirement years. Hal Stanley was there, a forester, former Deputy Minister and Clerk of the Privy Council. Hal's picture appears on a very early CFS report about the work at the station-a lot younger then as he was one of the very first students to work at the North Pond site. His photo was taken again in the very same tree plot 50 years later. Hal has been a long-time member and great supporter of the CIF/IFC. Two other special guys were present: Dr. John Munro, a former CFS Director, longtime CIF/IFC member and another Tree of Life recipient, and Bob Van Nostrand. Known affectionately as Bob Van he was one of the original researchers with the CFS in Newfoundland and Labrador and in 2005 received the CIF/IFC award for 50 years of membership-over half a century of commitment, and still participating and giving to the Institute. WOW! Thank you Bob and thank you Ed, Hal and John.

So this is my sixth and last Perspective and my Presidency soon winds down. I used the term "WOW" a couple of times in my first Perspective describing the great success we had with the Jasper conference and a couple times here in a different but related contextWOW! is about this organization, its members and its activities. I am pleased to have been of service to this fine Institute and to its members. The year has not been all that easy. On a very sad note our Executive Director, John Pineau, lost his wonderful son, Michael, and we all grieved with him. And as an Institute we continue to struggle with membership and finances-but with long-term strategic planning, support from all the Sections, and with the support and initiative of our many commit- ted members we will rebuild and continue to be successful.

As an Institute we have great programs and activities and many great members. Great members like Bob Van and Ed Blackmore that have given this Institute a lot and are still giving. But are we giving value back to them? Well I think so and maybe I don't need to think too deeply about this but quite simply I think we provide value by "being there" and by continuing with some great and wonderful traditions (like field tours) and by building new programs (Forest without Borders). We all have busy careers, belong to other organizations, but in Canada and in our individual provinces, the CIF/IFC provides a bond amongst and a service to forest practitioners that maybe we are too busy to see. Think about the conferences, the field tours, seminars, and the many other activities taking place across the country. In our 18 Sections there is something on the go for everyone! With over 100 years behind us we have a fine and valued legacy and it's time to begin to build the next one.

So as I move on and join the ranks of our more senior guys I want to thank the CIF/IFC for being there over the years. I haven't read all The Chronicle articles, made all the Section meetings nor, forgive me, been a member for all my career, but I do want the CIF/IFC to be there for me and to be there for all forest practitioners. It is a place to reconnect with peers, with friends and co-workers, a place to grow as a professional. We have a great Institute as it stands now-we just need to be a little bigger and to be here a lot longer.

All the best; join the team, join the CIF/IFC. 
on, d'accord. Soyons sérieux pour un instant. Si vous prenez le titre de ce texte au pied de la lettre et si vous le lisez en pensant que je vais vous fournir quelques indications sur le sujet, alors cest parfait. Au moins, je vous aurai incités à poursuivre votre lecture.

Alors, s'il-vous-plaît, lisez ce texte en sachant que sérieusement le sens de la vie mest inconnu et que cette Perspective ne portera, si ce nest que brièvement, sur le sujet. J'ai eu de bons moments au cours du mois d'août dernier lors d'une excursion technique de la section Terre-Neuve et Labrador de l'IFC/CIF. Tout au long de la soirée et de la majeure partie du lendemain nous avons eu droit à des grillades et des boissons rafraîchissantes, à un petit déjeuner complet, à une pause-café accompagnée de muffins et à un magnifique déjeuner en plein air! WOW! Nous avons également eu l'opportunité de visiter le Centre de recherche North Pond... en somme, une autre activité pleinement réussie de l'IFC/CIF.

La station de recherche expérimentale de North Pond est un site d'essais sur le terrain du Service canadien des forêts qui fête ses 50 ans cette année et cette excursion visait à assister aux célébrations soulignant toutes ces années de travail et de permettre " un retour en arrière » pour plusieurs d'entre nous. Pour les autres membres ainsi que pour les plus jeunes, ceétait une opportunité de constater sur les lieux les résultats de certains essais de travaux sylvicoles conçus, planifiés et réalisés sur place principalement au cours du milieu des années 60 et au début des années 70 . C'était également une occasion de rencontrer et de recommuniquer avec certains des forestiers et des chercheurs actifs à cette époque. Une foule nombreuse a participé à l'excursion, les conditions climatiques ont été excellentes (toujours un plus ici à TerreNeuve), la nourriture était excellente et abondante et le tout nouveau bombardier à eau CL-415 de la province nous a survolés à quelques reprises au cours du déjeuner.

Deux choses se sont démarquées lors de cette excursion technique. Les essais réalisés à l'origine étaient intéressantsplusieurs espèces d'arbres ont été plan- tées ainsi que plusieurs provenances et suivant de nombreux dispositifs. La station de North Pond est d'une superficie de 1500 ha environ et est issue des cendres engendrées par les feux de forêt de 1961 qui ont ravagé l'île. La présence du Service canadien des forêts était relativement récente dans la province à cette époque et certains des premiers forestiers et chercheurs d'alors avaient des contacts avec les Îles britanniques (Écosse) et la Colombie-Britannique. En conséquence, certains des essais initiaux affichaient une certaine influence britannique. Les espèces de la Côte ouest, qui étaient communément plantées au cours de l'après-guerre en Grande-Bretagne, faisaient partie des essais (plusieurs nont pas survécu aux rigueurs climatiques). Plusieurs autres espèces nordiques plus communes ont été plantées et ont démontré des résultats variables.

Tel qu’indiqué précédemment, l'excursion a regroupé de nombreuses personnes. Plusieurs jeunes forestiers ont participé à l'activité, mais les quelques groupes de participants qui ont semblé apprécier encore plus leur journée étaient composés de personnes comme moi, proches de leur retraite et qui avaient passé une partie de leur formation en tant quétudiants à mesurer (et à mesurer encore!) chacun des éléments de ces essais, ainsi qu'un groupe très spécial de personnes retraitées depuis quelques années. Je vais citer des noms compte tenu qu'il sagit de personnes vraiment spéciales : Ed Blackmore était sur place et avait organisé l'excursion. Ed est un membre de longue date de l'IFC/CIF, un récipiendaire du prix de l'Arbre de la vie et demeure très actif au cours de sa retraite. Hal Stanley a participé à l'activité, un forestier, ancien sous-ministre et greffier du Conseil privé. Une photographie de Hal a été publiée dans un des tous premiers rapports sur les travaux réalisés à la station-nous le montrant beaucoup plus jeune alors qu'il était l'un des premiers étudiants à travailler au Centre North Pond. Il a été photographié à nouveau dans la même parcelleéchantillon, 50 ans plus tard. Hal est un membre de longue date et un fervent supporteur de l'IFC/CIF. Deux autres personnes très spéciales étaient présentes : le Dr John Munro, un ancien directeur du SCF, membre de longue date de l'IFC/CIF et également récipiendaire du prix de l'Arbre de la vie, ainsi que Bob Van Nostrand. Amicalement appelé Bob Van, il a été l'un des premiers chercheurs du SCF à Terre-Neuve et Labrador et a reçu, en 2005, un prix de l'IFC pour ses 50 années d'adhésion à l'Institut-un engagement de plus d'un demi-siècle, tout en étant encore actif et impliqué au sein de l'Institut. WOW! Merci Bob et merci Ed, Hall et John.

Il s'agit de ma sixième et dernière Perspective et ma présidence prendra fin sous peu. J'ai utilisé l'expression «WOW » à quelques reprises dans ma première Perspective pour décrire le grand succès obtenu par le congrès annuel de Jasper et deux fois dans celleci dans un contexte connexe mais différent. Mes WOW! portent sur cette organisation, ses membres et ses activités. Je suis fier d'avoir été au service de ce remarquable Institut et de ses membres. Lannée n'a pas été facile pour nous tous. Je suis profondément peiné que notre directeur général John Pineau ait eu à connaître la perte de son fils bien-aimé Michael et nous lui offrons tous nos plus sincères condoléances. Et, en tant qu'Institut, nous tâcherons de freiner l'érosion du nombre de membres et de maintenir une bonne santé financièreet avec l'aide de notre planification stratégique à long terme, de l'appui de toutes les sections et du support et des initiatives de nos nombreux membres impliqués dans les activités de l'Institut, nous serons en mesure d'effectuer une reconstruction et de maintenir nos succès.

En tant qu'Institut, nous avons élaboré des programmes sensationnels et des activités stimulantes et nous pouvons compter sur des membres formidables. Des gens comme Bob Van et Ed Blackmore qui se sont impliqués sans compter pour l'Institut et qui poursuivent leur implication. Mais qu'est-ce que l'Institut leur offre en retour? Je crois, et ce sans avoir à trop creuser, qu'ils y trouvent une valeur intrinsèque simplement du fait que "l'Institut existe » et que nous maintenons quelques grandes et remarquables traditions (comme les 